\title{
Daerah Jelajah dan Penggunaan Ruang Kukang Jawa (Nycticebus javanicus) Di Taman Nasional Gunung Halimun Salak, Jawa Barat
}

\author{
Home Range and Space Use of Javan Slow Loris (Nycticebus \\ javanicus) in Halimun Salak Mount National Park, West Java
}

\author{
Eka Arismayanti ${ }^{1}$, Rd Roro Dyah Perwitasari ${ }^{*}$, Indah Winarti \\ 'Departemen Biologi, Fakultas Matematika dan Ilmu Pengetahuan Alam, Institut Pertanian Bogor, \\ Kampus IPB Dramaga, Bogor 16680 \\ ${ }^{2}$ Pusat Rehabilitasi Satwa-Yayasan IAR Indonesia, Bogor 16610
}

Diterima 12 Desember 2017/Disetujui 20 Februari 2018

\begin{abstract}
Javan slow loris (Nycticebus javanicus) is a slow moving nocturnal prosimian primate. Javan slow lorises are considered critically endangered by International Union for the Conservation of Nature. To date, there is limited source information available regarding wild loris ecology and behavior. In this study, home range areas and use space of wild Javan slow loris was carried out in Mount Halimun-Salak National Park. This study aims to measure home range size and to analyze activity budgets in natural forest conditions. Kernel Home Range methods were used to analyze home range areas, while Point Centered Quarter methods were used to collect habitat data, and five minute Instantaneous-Focal Animal Sampling was used to observe and record behavioral data. Two adult female lorises were observed. Analysis showed contiguous home range sizes of 5.43 and 5.58 hectares for Individuals I and II, respectively. These home ranges were larger than that reported in Malaysian Nycticebus coucang. Behavioral analysis showed that daily activities were dominated by travel, feeding, active, and foraging, which took place primarily in the lower canopy stratum, whereas sleeping typically occurred in the medium canopy stratum. The use of space of Javan slow loris correlated with height, substrat, contact, and size of branch.
\end{abstract}

Key words: Core area, sleeping tree, kernel home range, lower canopy

\section{PENDAHULUAN}

Latar Belakang. Kukang jawa merupakan satwa nokturnal yang termasuk dalam ordo Primata, famili Lorisidae, genus Nycticebus, spesies Nycticebus javanicus. Lima spesies kukang yang tersebar di kawasan asia yaitu Nycticebus bengalensis, $N$. pygmaeus, $N$. coucang, N. menagensis, dan N. javanicus (Gambar 1). Tiga dari lima jenis kukang berada di Indonesia tersebar di daerah Kalimantan, Sumatera, dan Jawa, yaitu kukang malaya (N. coucang), kukang borneo ( N. menagensis), dan kukang jawa ( $N$. javanicus).

Kukang jawa merupakan satwa endemik Pulau Jawa. Saat ini, kukang jawa banyak diburu dan diperdagangkan sebagai hewan peliharaan. Perdagangan kukang jawa menyebabkan populasi kukang jawa di alam terancam. Faktanya kukang jawa termasuk satwa yang dilindungi. Informasi dan data ekologi mengenai kehidupannya di alam pun masih sangat sedikit.

*Penulis korespondensi:

E-mail: witafar@yahoo.com
Data ekologi mengenai kukang jawa diperlukan untuk membantu proses konservasi secara exsitu maupun in-situ. Salah satu data ekologi yang diperlukan yaitu daerah jelajah dan penggunaan ruang habitat. Daerah jelajah (home range) adalah daerah yang digunakan satwa secara tetap, karena daerah tersebut dapat menyediakan makanan, minum, tempat berlindung, tempat tidur, dan tempat kawin. Penggunaan ruang di suatu habitat memiliki peranan penting untuk mengetahui penggunaan stratum hutan dan jenis substrat oleh satwa dalam melakukan aktivitasnya. Penelitian mengenai daerah jelajah kukang yang ada baru dilakukan pada kukang Malaya, dan kukang jawa hasil rehabilitasi Yayasan International Animal Rescue Indonesia (YIARI). Daerah jelajah harian (daily range atau night range pada satwa nokturnal) kukang jawa liar belum diketahui. Penelitian daerah jelajah dan penggunaan ruang habitat kukang jawa di alam liar perlu dilakukan. Mengingat populasi kukang jawa yang semakin sedikit akibat perburuan dan perdagangan bebas. Informasi tersebut dapat 
membantu dalam mengetahui tingkat keberhasilan pengelolaan rehabilitasi dan reintroduksi kukang jawa di alam liar. Informasi yang diperoleh akan menjadi salah satu parameter dalam pengelolaan kukang jawa secara in-situ maupun ex-situ.

Perumusan Masalah. Kukang sudah tercantum dalam satwa yang dilindungi oleh pemerintah Indonesia sejak tahun 1990. Semua jenis kukang termasuk dalam Apendiks I menurut CITES (2007). Status konservasi kukang jawa sudah meningkat menjadi kritis (critically endangered) menurut IUCN (2013). Akan tetapi, data mengenai daerah jelajah kukang jawa di alam masih sangat sedikit. Di lain pihak data tersebut sangat diperlukan untuk program konservasi baik ex-situ maupun in-situ mengingat jumlah populasi satwa ini terus menurun. Oleh karena itu, kajian tersebut perlu dilakukan dengan harapan dapat dimanfaatkan dalam program konservasi satwa ini.

Penelitian mengenai daerah jelajah dan penggunaan ruang harian kukang jawa baru dilakukan di beberapa daerah di Jawa Barat, namun hal tersebut masih dirasa kurang untuk mengetahui data ekologi kukang jawa liar di Indonesia. Oleh karena itu perlu dilakukan pengukuran daerah jelajah kukang jawa dan menganalisis penggunaan ruang kukang jawa di Taman Nasional Gunung Halimun Salak. Informasi yang diperoleh akan menjadi salah satu parameter dalam pengelolaan kukang jawa secara in-situ maupun ex-situ agar populasi kukang jawa tetap lestari.

Tujuan Penelitian. Penelitian ini bertujuan untuk mengukur daerah jelajah dan menganalisis penggunaan ruang harian kukang jawa.

Manfaat Penelitian. Hasil penelitian ini diharapkan dapat menjadi informasi awal kondisi ekologi kukang jawa serta menjadi data awal untuk penelitian ekologi lanjutan tentang kukang jawa di habitat hutan alami.
Data daerah jelajah dan penggunaan ruang kukang jawa dapat digunakan sebagai dasar ilmiah dalam penentuan kebijakan konservasi, serta menjadi salah satu parameter dalam pengelolaan kukang jawa secara in-situ maupun ex-situ (terutama dalam upaya rehabilitasi kukang jawa) agar populasi kukang jawa tetap lestari.

\section{BAHAN DAN METODE}

Waktu dan Tempat. Penelitian ini dilakukan di hutan habitat alami kukang jawa di Taman Nasional Gunung Halimun Salak, Jawa Barat selama empat bulan dari bulan Januari-April 2014. Lokasi penelitian dapat dilihat pada Gambar 2.

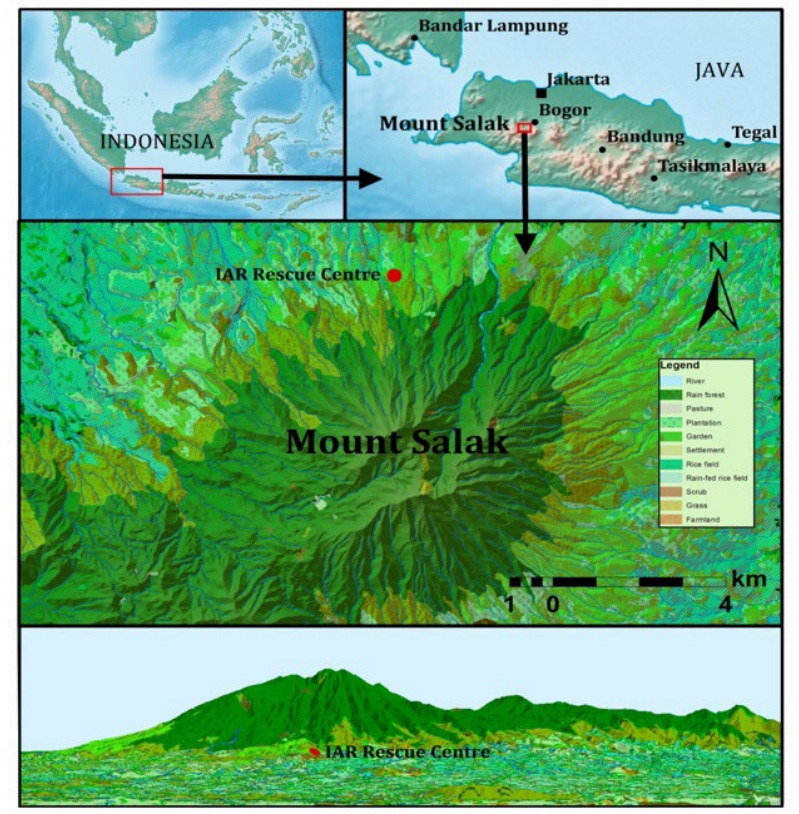

Gambar 2. Lokasi gunung salak dan Yayasan IAR Indonesia (Moore 2012)

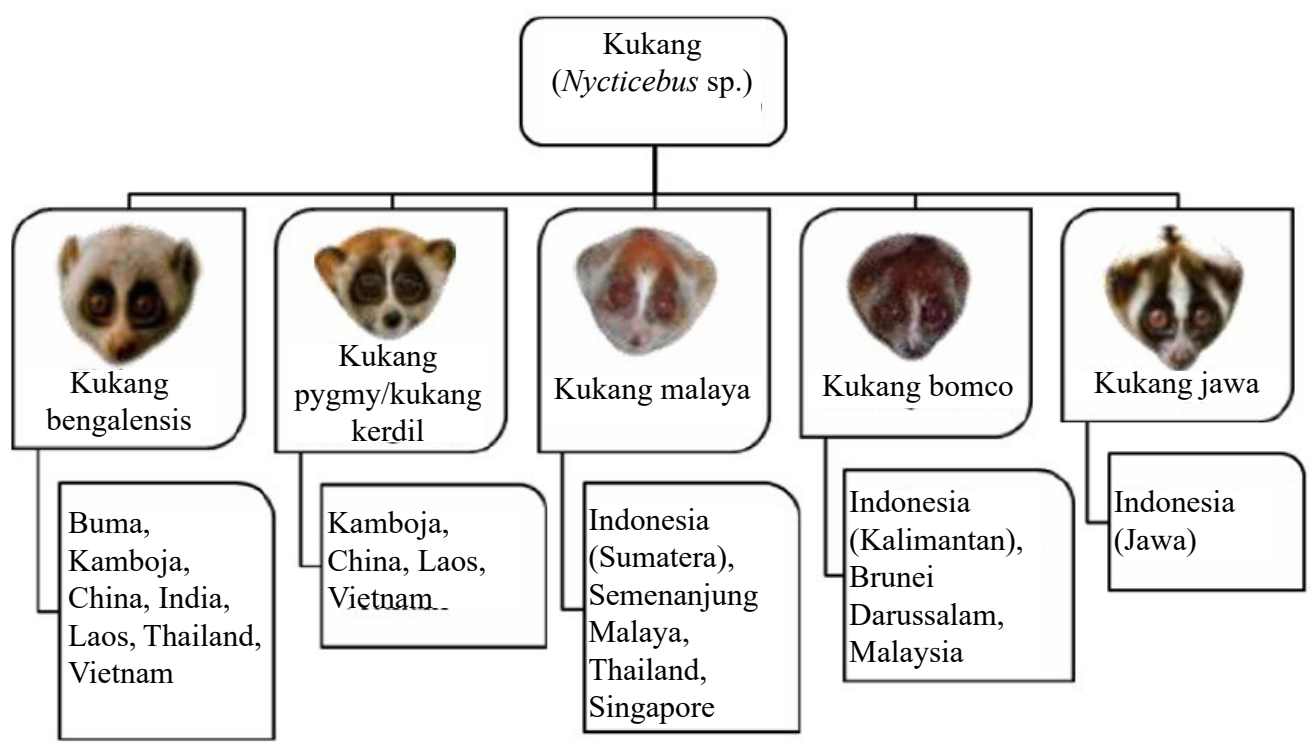

Gambar 1. Keanekaragaman dan sebaran jenis kukang di dunia (foto: Fitch-Snyder, Streicher, Widarteti, dan Winarti) 
Bahan. Bahan penelitian yang digunakan yaitu dua individu kukang jawa betina dewasa (Nycticebus javanicus) yang mendiami habitat hutan di Taman Nasional Gunung Halimun Salak (TNGHS) Bogor, Jawa Barat. Individu I yaitu kukang Ekar dan Individu II yaitu kukang Angel (Tabel 1).

Alat. Peralatan yang digunakan pada penelitian ini antara lain peta rupabumi, radio collar, receiver telemetry148-174 MHz R-1000, telonic antenna (Biotrack Yagi antenna), GPS (Global Positioning System) Garmin eTrex Vista CX, headlamp energizer 3 LED, senter Cree SWAT POLICE 50000 W T6 LED, jam tangan, higrometer, kamera Canon PowerShot A810 $H D$, meteran, kompas, kertas koran untuk herbarium, tabel data analisis vegetasi, dan tabel data perilaku.

Survey dan pemasangan radio collar. Survey pendahuluan dilakukan di daerah TNGHS untuk memastikan keberadaan kukang jawa liar di hutan. Pencarian kukang jawa dilakukan dengan menggunakan senter Cree dan headlamp, mulai pukul 18.00 sampai dengan $00.00 \mathrm{WIB}$ dan pukul 00.00 sampai dengan 06.00 WIB. Satu tim terdiri dari tiga hingga empat orang.

Kukang jawa yang ditemukan ditangkap dan dipasangi radio collar. Pemasangan radio collar dilakukan secara hati-hati agar tidak melukai leher kukang dan mengganggu aktivitas kukang. Pemasangan radio collar yang terlalu ketat dapat menyebabkan luka dan memengaruhi perilaku alami kukang jawa. Pemasangan radio collar yang terlalu renggang dapat menyebabkan radio collar terlepas. Tim yang memasangkan radio collar memakai sarung tangan serta masker sebagai prosedur standar saat menangani kukang. Pemasangan radio collar tidak dilakukan pada individu yang belum dewasa (juvenile atau sub-adult) untuk menghindari gangguan, karena individu yang belum dewasa masih dalam masa pertumbuhan (Putri 2014). Setelah itu kukang dilepas kembali di habitat awal individu tersebut ditemukan. Individu yang baru dipasangi radio collar dibiarkan tanpa pengamatan perilaku selama dua malam untuk mengurangi efek stres dan untuk menyesuaikan diri. Selama kurang dari satu bulan kukang diamati dan dipantau sebagai proses pembiasaan, untuk melihat adaptasi kukang terhadap radio collar dan pengamat. Setelah kukang terbiasa,

Tabel 1. Identitas kukang jawa objek penelitian

\begin{tabular}{llr}
\hline Nama kukang & Nomor frekuensi & \multicolumn{1}{c}{ Ciri-ciri } \\
\hline $\begin{array}{l}\text { Individu I } \\
\text { (kukang ekar) }\end{array}$ & 151.4010 & $\begin{array}{r}\text { Bunting, tubuh lebih bulat, } \\
\text { pola garpu dan garis } \\
\text { punggung sangat jelas } \\
\text { berwarna coklat tua. }\end{array}$ \\
$\begin{array}{l}\text { Individu II } \\
\text { (kukang angel) }\end{array}$ & 151.3325 & $\begin{array}{r}\text { Memat badan 950 g. } \\
\text { tungkai kiri atas, pola } \\
\text { garpu di mata lebih }\end{array}$ \\
& & \begin{tabular}{l} 
pudar. \\
\hline
\end{tabular} \\
\hline
\end{tabular}

kemudian dilakukan pemantauan secara bergantian selang satu hari dengan menggunakan receiver telemetry 148-174 MHz R-1000 dan telonic antenna. Titik koordinat lokasi ditemukannya kukang ditandai dengan GPS selama 15 menit sekali saat perjumpaan langsung. Penentuan waktu 15 menit dilakukan dengan pertimbangan waktu 15 menit merupakan waktu yang cukup untuk merekam perpindahan kukang (YIARI 2014).

Monitoring (Pemantauan). Kegiatan pemantauan dimulai pukul 18.00 sampai dengan pukul 00.00 WIB atau dari pukul 00.00 sampai dengan pukul 06.00 WIB (Gambar 3). Istirahat selama pemantauan dilakukan setelah tiga jam pengamatan, istirahat dilakukan selama satu jam. Observasi perilaku dan pengambilan titik kordinat GPS dilakukan pada saat perjumpaan dengan satwa secara langsung selama 15 menit sekali. Apabila satwa tidak ditemukan saat pemantauan, maka pengambilan data observasi tidak dilakukan. Pengambilan data satu titik kordinat GPS dilakukan pada jam terakhir pemantauan dengan sinyal yang paling tinggi. Dalam satu tim monitoring terdiri atas tiga hingga empat orang, Alat yang digunakan untuk pemantauan yaitu radio collar, receiver telemetry 148-174 MHz R-1000, telonic antenna, GPS, headlamp energizer $3 L E D$, senter Cree, jam tangan, buku perilaku, higrometer, dan kamera. Receiver dan antenna telonic digunakan untuk mencari lokasi kukang tersebut melalui sinyal yang berasal dari radio collar, GPS untuk menandai titik koordinat daerah jelajah dimana kukang ditemukan setiap 15 menit, headlamp dan senter Cree digunakan untuk penerangan dalam mencari kukang, jam tangan dan buku perilaku untuk mencatat setiap perilaku kukang setiap lima menit, higrometer untuk mengukur kelembaban dan suhu lingkungan, dan kamera untuk dokumentasi. Penentuan interval waktu pengambilan data perilaku setiap lima menit, dilakukan dengan pertimbangan bahwa lima

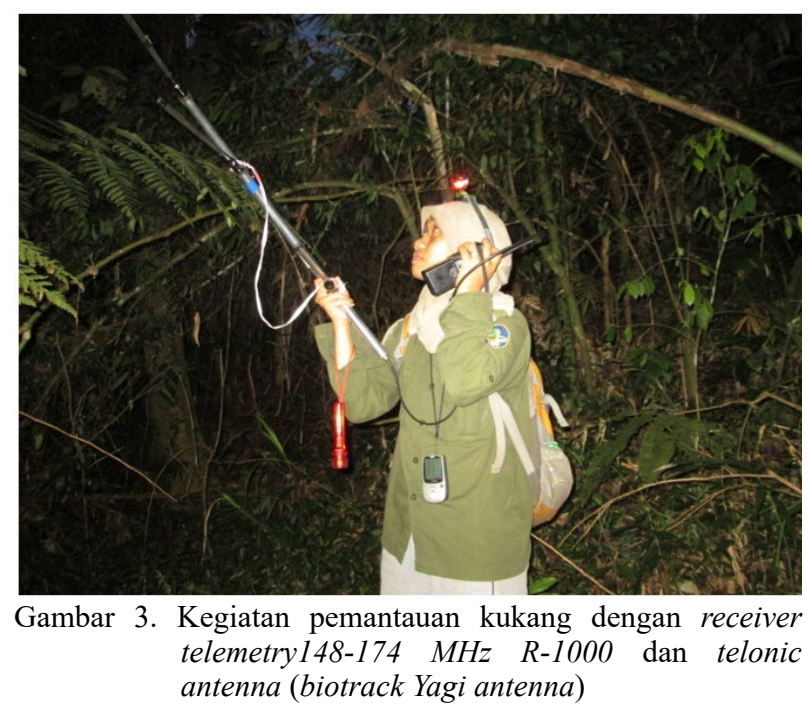


menit merupakan waktu yang cukup untuk merekam pergerakan kukang.

Telemetri merupakan teknologi yang memudahkan deteksi keberadaan satwa (Rodgers 2001). Radio telemetri memanfaatkan pemancar yang dipasangkan pada satwa, pemancar tersebutmemancarkan gelombang radio yang ditangkap oleh penerima gelombang melalui antenna. Telemetri memudahkan penelitian terhadap satwa yang sulit untuk dibedakan satu sama lain, sulit untuk ditemukan atau samar dan satwa yang hidup nokturnal (Juarez et al. 2011). Radio telemetri memiliki ukuran yang kecil sehingga sesuai untuk satwa yang berukuran kecil. Prinsip kerjanya menggunakan perangkat pemancar (radio transmitter) yang dipasangkan pada satwa dan memancarkan gelombang radio pada frekuensi tertentu yang diterima oleh pengamat menggunakan perangkat penerima (radio receiver) melalui antena (Rodgers 2001). Perangkat pemancar yang dipasangkan pada satwa akan memancarkan gelombang radio pendek. Oleh karena itu, berat dan besar baterai disesuaikan dengan satwa yang diteliti yaitu kurang dari $2 \%$ dari bobot tubuh satwa (Gursky 1998).

Satwa yang telah dipasangi collar akan diidentifikasi sesuai dengan frekuensi dari tiap pemancar. Gelombang yang dipancarkan perangkat pemancar akan ditangkap dengan bantuan antena dalam bentuk getaran listrik pada perangkat penerima. Perangkat penerima kemudian memperkuat gelombang yang ditangkap dan mengubahnya menjadi sinyal suara yang dapat didengar sebagai bunyi 'beep' (Mech 1983; Thohari 1989). Setiap radio collar memiliki frekuensi yang berbeda. Kabel antena dihubungkan dengan receiver, kemudian nomor frekuensi kukang dimasukan ke penerima sinyal untuk mencari lokasi kukang yang hendak diamati. Antena diputar untuk menentukan arah lokasi kukang. Sinyal yang ditangkap ditandai dengan bunyi 'beep'yang diterima oleh penerima sinyal, semakin kuat bunyi dan semakin tinggi frekuensi pada receiver (frekuensi 10 hingga 100), menandakan bahwa lokasi kukang semakin dekat. Posisi kukang dipastikan menggunakan lampu senter Cree dengan mendeteksi keberadaan kukang melalui sinar pantul mata. Posisi kukang juga dapat diketahui melalui vokalisasi saat kukang melakukan aktivitas sosial dengan individu lainnya. Individu I dan II dapat dilihat pada Gambar 4 dan 5.

\section{Prosedur Analisis Data.}

Daerah Jelajah. Metode Kernel Home Range digunakan untuk mengetahui daerah jelajah satwa tersebut. Metode ini mencakup semua titik-titik koordinat yang sering dikunjungi sehingga dapat membentuk suatu pola daerah jelajah yang sering digunakan (Worton 1989). Analisis daerah jelajah dilakukan dengan bantuan program komputer Map

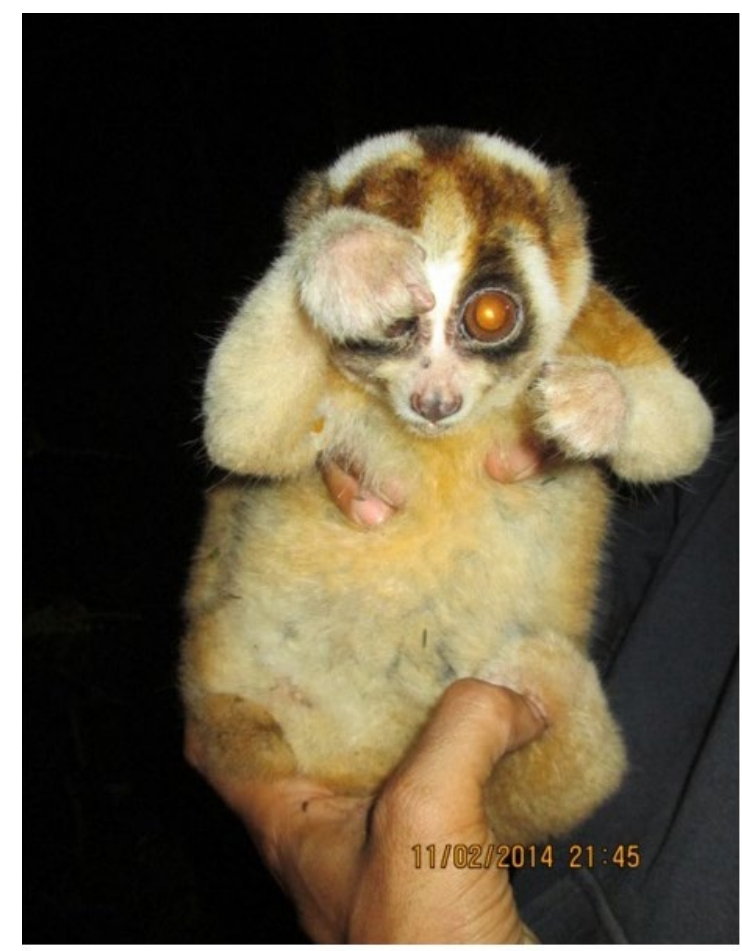

Gambar 4. Individu I (kukang ekar)

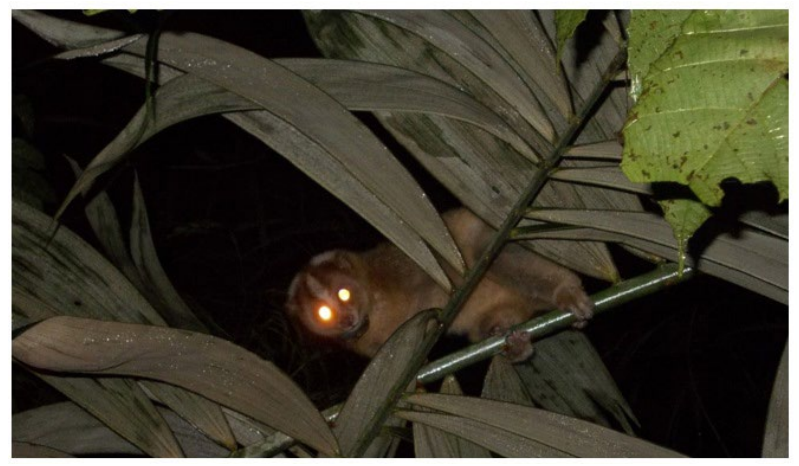

Gambar 5. Individu II (kukang angel)

Source, ArcGIS 10, Geospatial Modelling Environment, dan Open Jump. Hasil dari analisis tersebut berupa gambaran peta daerah jelajah. Pengubahan format File dilakukan dalam Map Source, File yang di dapatkan dari GPS berupa File GDB akan dirubah dalam bentuk GPX agar dapat diolah dalam ArcGIS (Gambar 6).

Apabila data telah terbaca maka akan muncul waypoint dan terbentuk titik-titik daerah dalam peta (Gambar 7). File GPX kemudian diubah menjadi SHP agar dapat diolah menjadi peta, peta dapat berupa point koordinat, atau analisis polygon untuk mengetahui luas daerah sementara. Berdasarkan waypoint tersebut juga dapat diketahui kecepatan dan jarak yang dapat ditempuh oleh individu kukang tersebut selama masa penelitian.

Analisis daerah jelajah dengan metode kernel home range dapat dilakukan dengan Geospatial Modelling Environment. File koordinat diolah menjadi format kde dengan bandwith PLUGIN dan cell size 5, setelah itu tampilan peta akan membentuk 


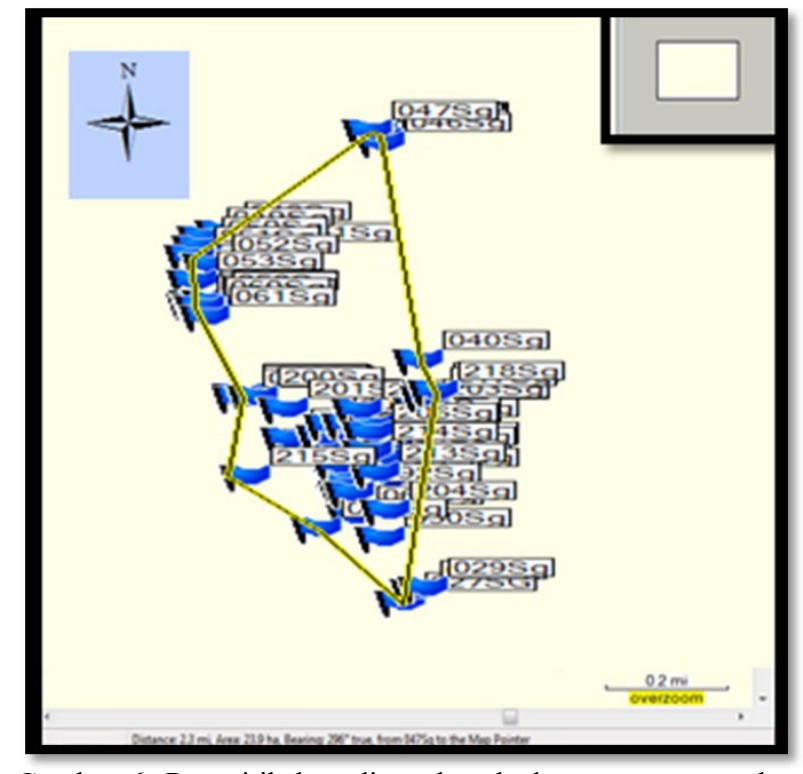

Gambar 6. Peta titik koordinat daerah dengan menggunakan Map Source

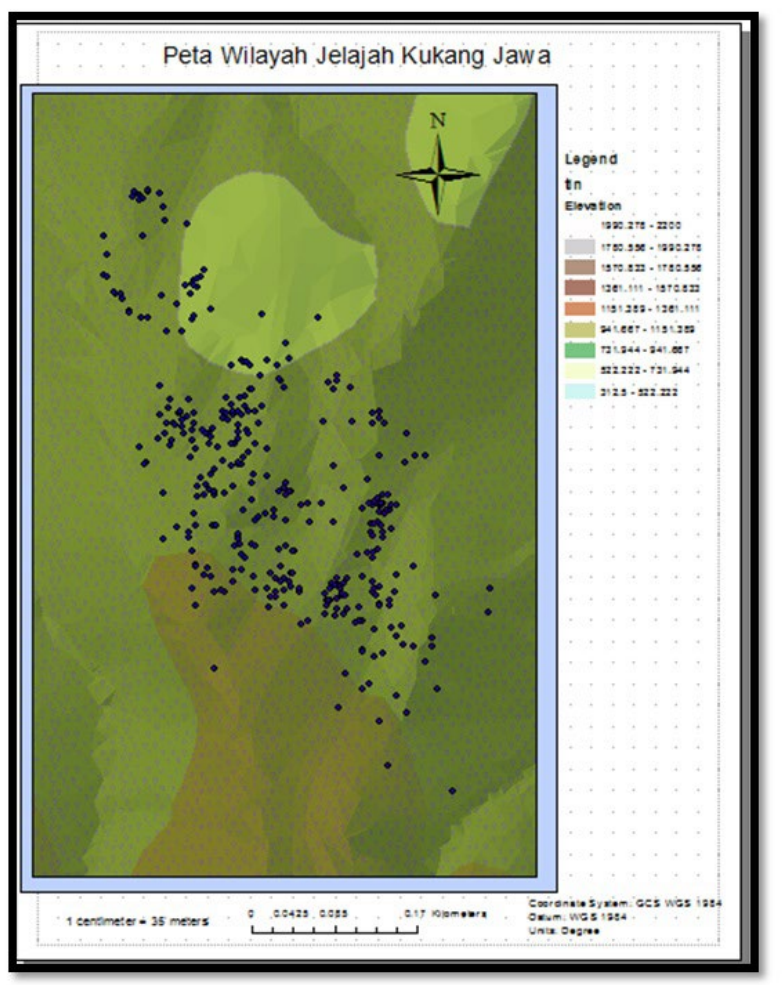

Gambar 7. Peta titik koordinat daerah jelajah dengan menggunakan ArcGIS 10.1

kontur dengan gradasi warna yang berbeda. Gradasi warna yang berbeda menunjukkan frekuensi kukang saat mengunjungi daerah jelajah, dan membentuk daerah inti (Gambar 8). File diolah dengan format isopleth dengan quantiles 0.90 , maka hasil yang didapatkan adalah garis tepi daerah jelajah dan ukuran luas area. Untuk mengetahui luas daerah inti dapat dilakukan dengan cara merubah quantiles menjadi 0.5. Analisis pertambahan luas daerah jelajah selama masa penelitian dilakukan dengan menggunakan software Open Jump. Open Jump digunakan untuk membuat grafik asimtot dengan memasukkan hasil titik koordinat, untuk diolah ke dalam perangkat lunak tersebut. Hasil dari analisis tersebut berupa gambaran peta daerah jelajah dan grafik asimtot pertambahan luasan daerah jelajah (Gambar 9).

Pengamatan Tipe Vegetasi. Metode titik pusat kuadran (point centered quarter) digunakan untuk mengetahui tipe vegetasi yang didiami oleh satwa tersebut. Metode ini memanfaatkan pengukuran jarak antar individu tumbuhan atau jarak dari pohon yang dipilih terhadap individu-individu tumbuhan yang terdekat. Pembagian areal sekitar titik contoh menjadi empat kuadran yang berukuran sama, pohon di setiap kuadran yang letaknya paling dekat dengan titik pengukuran diukur jarak, lebar, dan tinggi pohon tersebut (Gambar 10).

Pengukuran pohon hanya dilakukan terhadap keempat pohon yang terpilih (Kusmana 1997). Titik pusat kuadran dibuat pada lokasi pohon yang menjadi tempat individu kukang jawa tidur. Analisis vegetasi dilakukan dengan menghitung nilai jarak rata-rata, kerapatan jenis, kerapatan relatif, frekuensi jenis, frekuensi relatif, dominansi jenis, dan dominansi relatif yang selanjutnya dihitung untuk menghasilkan indeks nilai penting (INP) (Kusmana 1997). Semakin tinggi nilai INP suatu spesies terhadap spesies lainnya, semakin tinggi peranan spesies pada komunitas tersebut. Identifikasi tumbuhan dilakukan di lokasi pada siang hari. Identifikasi tumbuhan dilakukan di lapang pada siang hari. Identifikasi dilakukan untuk mengenali jenis vegetasi pakan dan bagian yang dimakan (kulit pohon, getah, buah, dan bunga), serta jenis vegetasi untuk tidur. Jenis tumbuhan yang telah diidentifikasi dicek klasifikasinya di situs The International Plant Names Index dan Plantamor.org. Inventarisasi jumlah pohon pakan dilakukan pada pohon yang paling sering digunakan kukang saat feeding selama pengamatan. Plot yang digunakan sebanyak enam plot, dengan luas masing-masing plot sebesar $10 \mathrm{~m}^{2}$. Jumlah dan jenis pohon dalam plot tersebut kemudian dihitung.

Pola Penggunaan Ruang. Pengumpulan data primer pola penggunaan ruang dilakukan dengan melakukan pengamatan aktivitas dan pola pergerakan, jalur lintasan dan daerah jelajah kukang pada satu individu tertentu dengan metode instantaneous-focal animal sampling (Martin dan Bateson 1993). Analisis pola penggunaan ruang dilakukan dengan analisis aktivitas, dan hubungan tipe aktivitas dengan tipe vegetasi menggunakan uji chi-square (Santosa et al. 2011). Pengamatan dilakukan mulai dari pukul 18.00-00.00 WIB dan 00.00-06.00 WIB. Pengumpulan data perilaku 


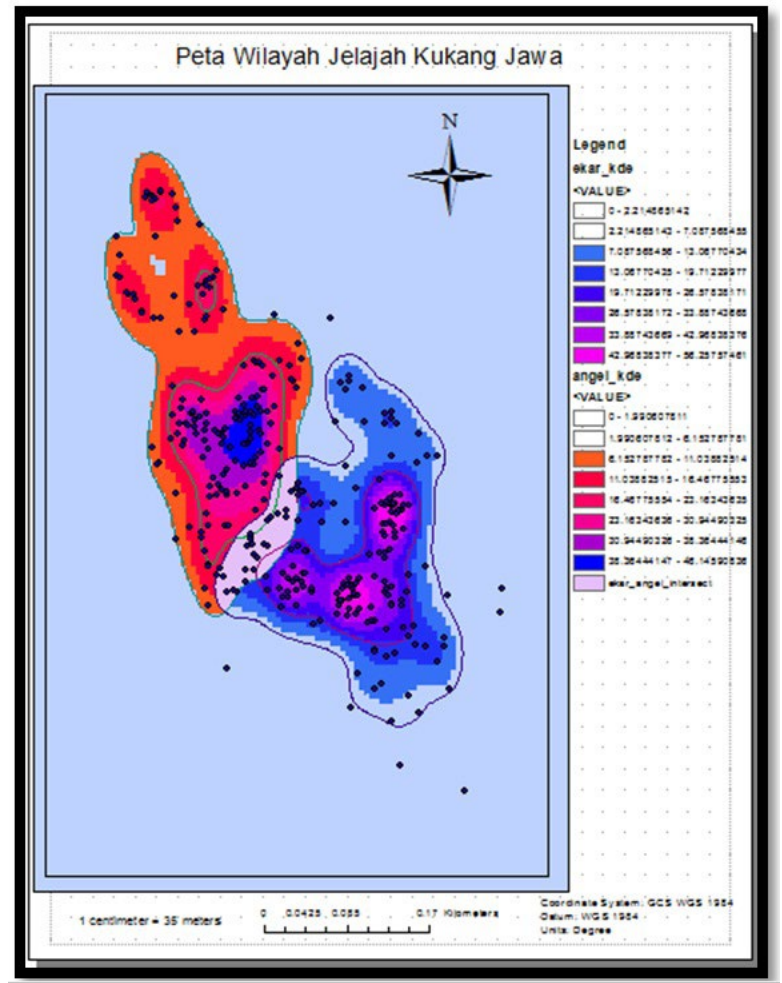

Gambar 8. Hasil luasan area daerah jelajah kukang dengan menggunakan GME

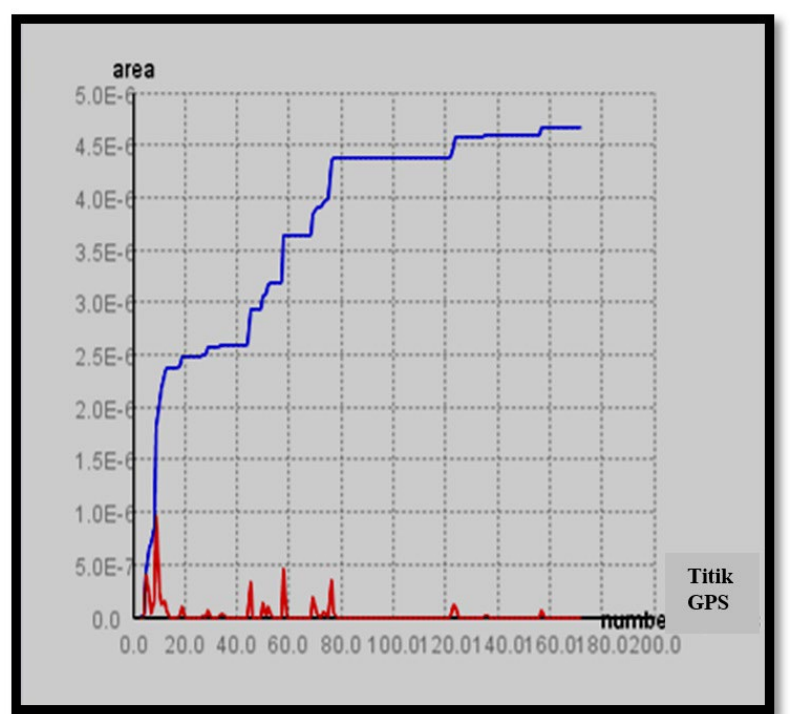

Gambar 9. Grafik asimtot pertambahan luas daerah jelajah satwa

mengikuti ethogram yang dimodifikasi oleh Yayasan IAR Indonesia berdasarkan ethogram Fitch-Snyder et al. (2011) serta Glassman dan Wells (1984). Data yang dicatat berupa waktu pengamatan, perilaku, ketinggian satwa di substrat, jenis substrat, posisi di pohon, ukuran substrat, dan ketinggian substrat. Penggunaan ruang ditunjukkan melalui penggunaan ketinggian oleh satwa, penggunaan posisi di pohon, dan penggunaan ukuran substrat dalam beraktivitas. Posisi di pohon dikategorikan menjadi tepi, tengah, puncak, batang dan lain-lain. Tipe substrat yang digunakan kukang di lokasi pengamatan adalah pohon.

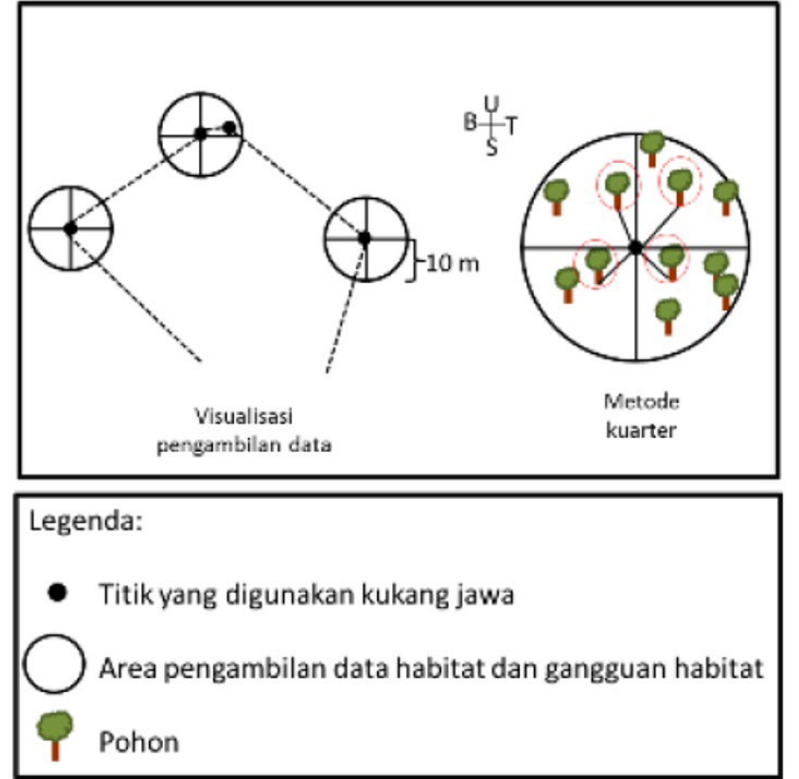

Gambar 10. Plot pengukuran pohon dengan metode kuadran (Putri 2014)

Ukuran cabang pohon dibagi menjadi lima sesuai dengan kebutuhan kukang dewasa, yaitu ranting kecil (dapat digenggam kedua tangan sepenuhnya oleh telapak kukang, tidak dapat menopang berat tubuh kukang), ranting besar (kukang dapat menggantung), cabang kecil (kukang dapat berjalan diatas cabang dan cabang dapat menopang berat tubuh kukang), cabang besar (kukang dapat berjalan diatas cabang, namun telapak tangan tidak dapat memegang seluruhnya), batang (kukang tidak dapat memegang penuh, hanya dapat memegang celah kulit pohon). Catatan tambahan mengenai perilaku lainnya dan keberadaan predator potensial selama pengamatan dicatat dalam keterangan tambahan (YIARI 2014). Analisis pola penggunaan ruang dilakukan dengan menganalisis aktivitas dan tipe vegetasi menggunakan uji chi-square (Santosa et al. 2011) pada perangkat lunak SPPS Statistic 17.0. Tingkat kepercayaan yang digunakan pada $p \leq 0.05$ dan $p \geq 0.05$. Bila nilai $p$ value lebih besar dari 0.05 , maka tidak ada perbedaan secara nyata penggunaan kategori penggunaan ruang dalam perilaku kukang jawa (terima $\mathrm{H} 0$ ). Bila nilai $p$ value lebih kecil dari 0.05 , maka ada perbedaan secara nyata penggunaan kategori penggunaan ruang dalam perilaku kukang jawa (terima $\mathrm{H} 1$ ). Pengamatan dilakukan mulai dari pukul 18.00-00.00 WIB dan 00.00-06.00 WIB.

\section{HASIL}

Luas Daerah Jelajah Kukang Jawa. Analisis luas daerah jelajah kukang jawa dilakukan dengan metode kernel home range, metode ini digunakan untuk mengetahui daerah inti yang digunakan kukang jawa (Gambar 11). Daerah berwarna biru 


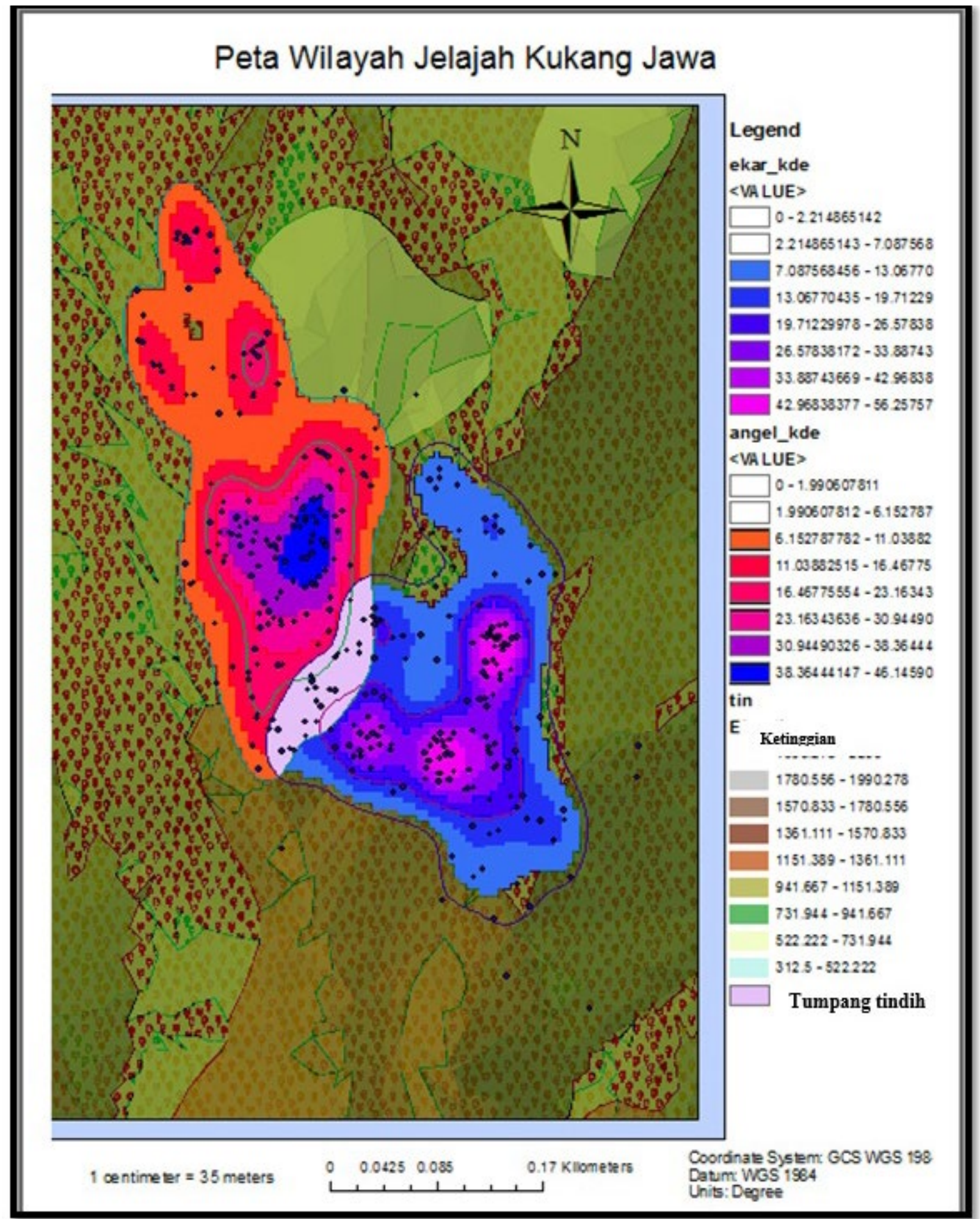

Gambar 11. Peta luas daerah jelajah kukang jawa dengan metode kernel home range

adalah daerah Individu I. Daerah berwana oranye adalah daerah Individu II. Titik-titik yang terdapat dalam peta merupakan koordinat perjumpaan langsung dengan tiap individu kukang.

Daerah jelajah individu I berada di ketinggian 941.66 hingga $1361.1 \mathrm{~m}$ dpl. Daerah inti individu I, ditandai garis batas berwarna merah muda dengan tiga daerah inti, berada di ketinggian hingga 1361.1 $\mathrm{m}$ dpl. Intensitas penggunaan daerah inti sebesar 42.96 hingga $56.25 \%$. Daerah jelajah individu II berada di ketinggian 941.66 hingga $1361.1 \mathrm{~m}$ dpl. Ketinggian daerah inti, ditandai dengan garis batas berwarna biru berada di 941.66 hingga $1151.3 \mathrm{~m}$ dpl. Intensitas penggunaan daerah inti sebesar 38.36 hingga $46.14 \%$. Daerah jelajah individu II terletak di antara $106^{\circ} 43^{\prime} 58.80^{\prime \prime}$ BT dan $6^{\circ} 40^{\prime} 55.20^{\prime \prime}$ LS. 
Pertambahan luas daerah jelajah paling besar terjadi pada bulan maret (garis hitam putih) sebesar 5.04 ha (Gambar 12).

Kukang individu I memiliki luas daerah jelajah sebesar 5.44 ha, yang terletak di antara $106^{\circ} 44^{\prime} 2.40^{\prime \prime}$ BT dan 6 $40^{\prime} 58.80^{\prime \prime}$ LS. Luas daerah individu I menyempit pada bulan maret menjadi 2.25 ha. Kukang individu II memiliki luas daerah jelajah yang lebih besar daripada individu I yaitu 5.58 ha. Tumpang tindih terjadi antara daerah jelajah individu I dan individu II pada $106^{\circ} 44^{\prime} 2.40^{\prime \prime}$ BT dan $6^{\circ} 40^{\prime} 55.20^{\prime \prime}$ LS. Daerah inti individu II lebih luas yaitu 1.77 ha dibandingkan dengan individu I yaitu 1.60 ha. Luas daerah tumpang tindih adalah 0.57 ha (Tabel 2).

Pada kurva asimtot individu I, terlihat bahwa garis kurva belum membentuk garis mendatar (Gambar 13). Hal ini menunjukkan bahwa luas

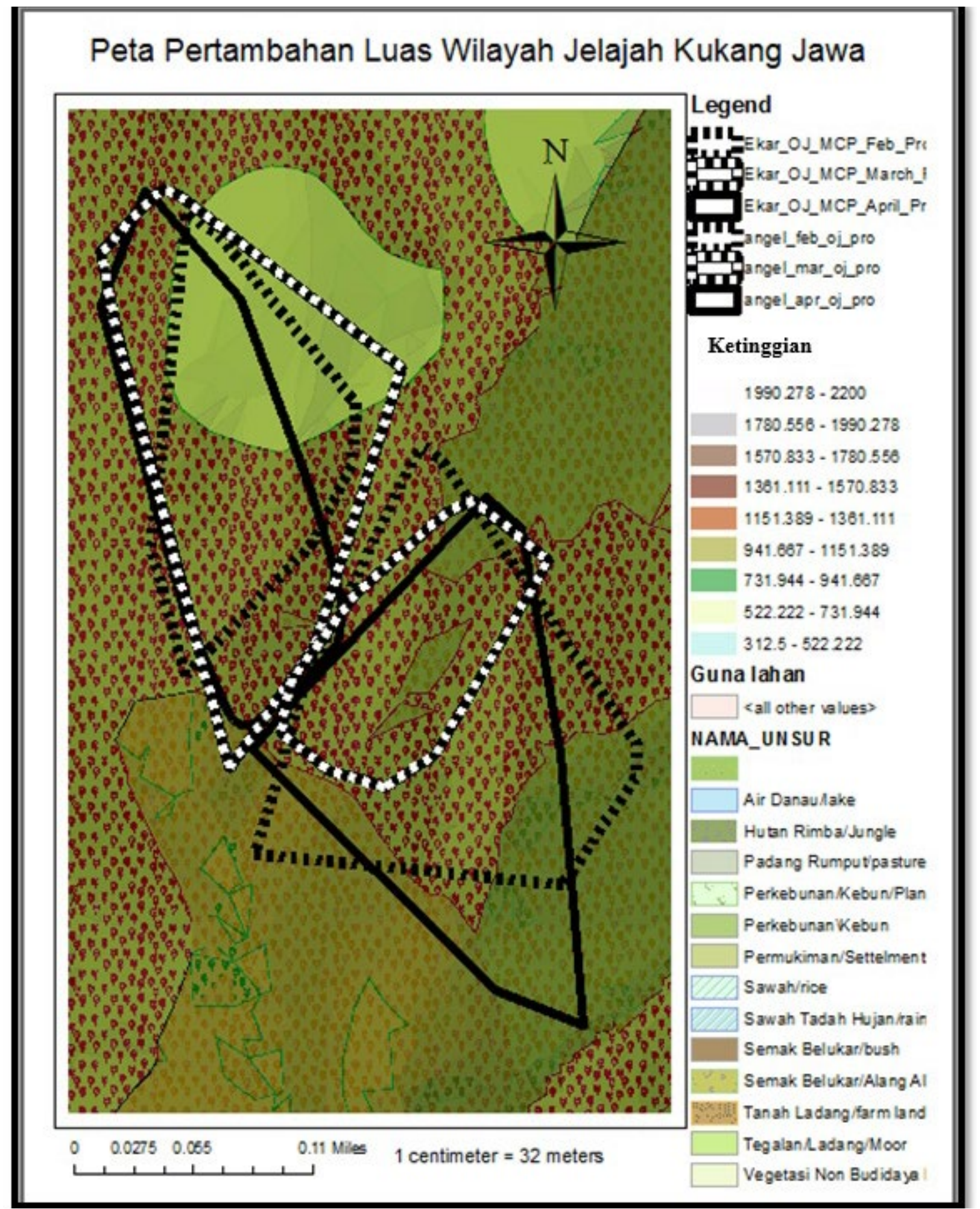

Gambar 12. Peta pertambahan luas daerah jelajah kukang jawa setiap bulan dengan Open Jump 
Tabel 2. Luas daerah jelajah kukang jawa

\begin{tabular}{|c|c|c|c|c|c|c|}
\hline \multirow[t]{2}{*}{ Kukang } & \multicolumn{3}{|c|}{ Bulan (ha) } & \multirow[t]{2}{*}{ Daerah inti (ha) } & \multirow[t]{2}{*}{ Total (ha) } & \multirow[t]{2}{*}{ Tumpang tindih (ha) } \\
\hline & Februari & Maret & April & & & \\
\hline Individu I & 5.39 & 2.24 & 5.02 & 1.60 & 5.43 & 0.57 \\
\hline Individu II & 3.05 & 5.04 & 3.68 & 1.77 & 5.58 & \\
\hline
\end{tabular}

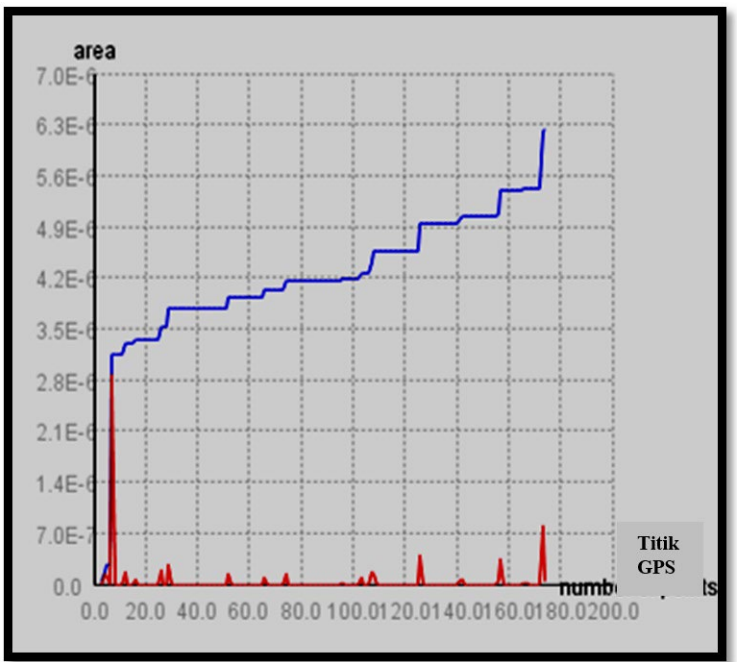

Gambar 13. Grafik asimtot pertambahan daerah jelajah (Februari-April 2014) individu I

daerah jelajah individu I masih bisa bertambah, dari besar luas daerah yang telah diteliti selama tiga bulan masa penelitian (Februari hingga April 2014). Daerah jelajah individu II pada kurva asimtot sudah menunjukan garis mendatar (Gambar 14). Hal ini menunjukkan bahwa tidak ada lagi penambahan luasan pada daerah jelajah individu II selama bulan Februari hingga April 2014. Dalam satu malam individu I dan II dapat menempuh jarak rata-rata 13 hingga $62.1 \mathrm{~m}$. Kukang yang diamati dapat menempuh jarak tersebut dengan kecepatan ratarata mencapai 1.42 hingga $1.53 \mathrm{~m} /$ menit.

\section{Penggunaan Ruang.}

Analisis vegetasi. Analisis vegetasi dilakukan untuk mengetahui preferensi pemilihan vegetasi dalam penggunaan ruang. Vegetasi yang dianalisis merupakan pohon lokasi tidur yang digunakan oleh kukang jawa (Tabel 3). Pohon tersebut digunakan sebagai titik contoh dalam setiap kuadran yang digunakan. Analisis vegetasi menggunakan enam petak contoh. Tidak ada kecenderungan pemilihan jenis pohon untuk tidur.

Pohon untuk tidur memiliki karakter tinggi 5 hingga 22 meter, serta dipenuhi dengan liana pada tajuk pohon tersebut. Kisampang mendominasi lokasi tempat tidur yang digunakan. Indeks Nilai Penting (INP) terbesar dimiliki oleh kisampang yaitu sebesar 211. Kukang menggunakan pohon untuk tidur yang memiliki tutupan tajuk sebesar $68 \%$. Jarak rata-rata antar pohon sebesar 5.4 meter. Rata-rata tinggi pohon adalah 17 meter, tinggi bebas

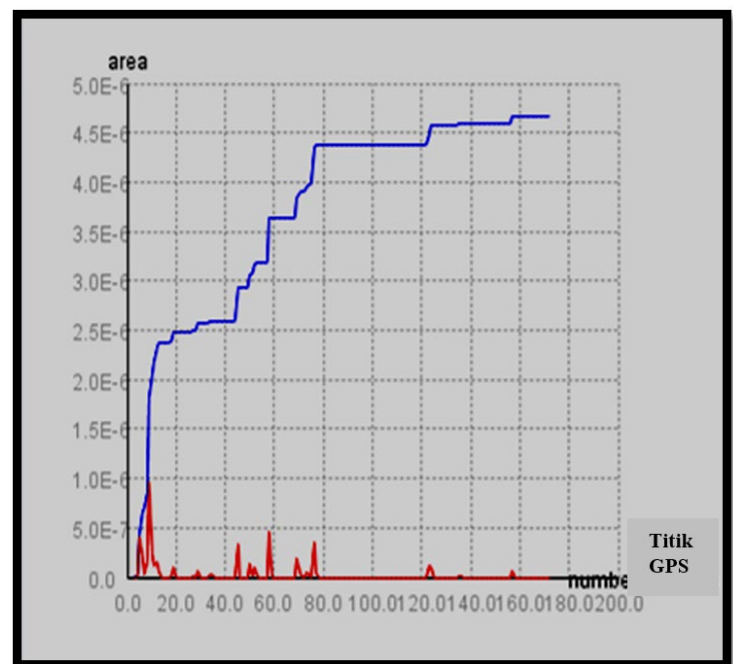

Gambar 14. Grafik asimtot pertambahan daerah jelajah (Februari-April 2014) individu II

cabang $8.99 \mathrm{~m}$, keliling batang pohon $138.65 \mathrm{~cm}$ dan rata-rata diameter batang pohon yaitu $44.15 \mathrm{~cm}$.

Pola Penggunaan Ruang Kukang Jawa. Tiga parameter pola penggunaan ruang yang digunakan oleh kukang jawa, yaitu jenis tumbuhan yang digunakan kukang, ketinggian posisi kukang di atas permukaan tanah dan ukuran cabang tumbuhan yang digunakan. Perilaku dominan individu I yaitu travel, aktif, dan feeding. Perilaku dominan individu II yaitu travel, dan feeding (Angeliza 2014).

Individu I lebih dominan menggunakan bungbuai (30.89\%), kaliandra (15.11\%), dan kisampang $(8.44 \%)$ sebagai tempat untuk beraktivitas. Ketinggian posisi individu I yaitu tujuh meter (17.11\%) dan delapan meter (10.22\%) untuk travel dan foraging. Individu I lebih sering menggunakan cabang kecil (49.78\%) untuk berpindah antar pohon, dan menggunakan ranting besar (20.67\%) untuk berpindah saat foraging. Individu II lebih dominan menggunakan kaliandra (44.50\%) dan bungbuai $(23.02 \%)$ sebagai tempat untuk beraktivitas. Ketinggian posisi individu II yaitu lima meter $(22.34 \%)$ dan dua meter (18.56\%), ketinggian tersebut digunakan saat feeding. Individu I lebih sering menggunakan cabang kecil (49.78\%) untuk berpindah antar pohon, dan menggunakan ranting besar $(20.67 \%)$ untuk berpindah saat foraging. Ukuran cabang yang sering digunakan oleh individu II yaitu cabang kecil $(43.30 \%)$ untuk melakukan aktivitas travel dan ranting kecil (30.24\%) untuk aktivitas foraging (Tabel 4). 
Tabel 3. Analisis vegetasi pohon tidur kukang jawa

\begin{tabular}{|c|c|c|c|c|c|c|}
\hline Nama lokal & Nama ilmiah & Famili & $\mathrm{KR}^{\mathrm{a}}$ & $\mathrm{DR}^{\mathrm{a}}$ & $\mathrm{FR}^{\mathrm{a}}$ & $\overline{\mathrm{INP}^{\mathrm{a}}}$ \\
\hline Kisampang & Evodia latifolia & Rutaceae & 73 & 94 & 44 & 211 \\
\hline Puspa & Schima wallichii & Theaceae & 8 & 3 & 11 & 22 \\
\hline Manglid & Manglietia glauca & Magnoliaceae & 4 & 1 & 11 & 16 \\
\hline Campaka gondok & Magnolia lilifera & Magnoliaceae & 4 & 1 & 11 & 16 \\
\hline Pasang & Quercus gemelliflora & Fagaceae & 4 & 1 & 11 & 16 \\
\hline Kaliandra & Calliandra calothyrsus & Fabaceae & 4 & 1 & 11 & 16 \\
\hline
\end{tabular}

KR: Kerapatan relatif, DR: Dominansi relatif, FR: Frekuensi relatif, INP: Indeks nilai penting

Tabel 4. Parameter penggunaan ruang kukang jawa di TNGHS

\begin{tabular}{lll}
\hline Parameter & Individu I & Individu II \\
\hline Substrat & $\begin{array}{c}\text { Bungbuai, kaliandra, } \\
\text { kisampang }\end{array}$ & Kaliandra, bungbuai \\
Ketinggian posisi & 7 dan $8 \mathrm{~m}$ & 5 dan $2 \mathrm{~m}$ \\
Ukuran cabang & $\begin{array}{c}\text { Cabang kecil dan } \\
\text { ranting besar }\end{array}$ & $\begin{array}{c}\text { Cabang kecil dan } \\
\text { ranting kecil }\end{array}$ \\
\hline
\end{tabular}

Berdasarkan hasil uji chi-square (Tabel 5) dari seluruh parameter penggunaan ruang yaitu ukuran cabang, ketinggian posisi dan jenis tumbuhan yang digunakan, diketahui bahwa nilai p lebih kecil dari 0.05 atau terima $\mathrm{H} 1$. Hal ini menunjukkan bahwa penggunaan seluruh parameter penggunaan ruang dalam tiap aktivitas berbeda nyata. Perbedaan ukuran cabang, ketinggian posisi dan jenis tumbuhan yang digunakan mempengaruhi pemilihan ruang habitat yang akan digunakan oleh kukang.

\section{PEMBAHASAN}

Daerah jelajah individu I dan II di lereng Gunung Salak masih memilki kisaran yang sama di ketinggian 941.66 hingga $1361.1 \mathrm{~m}$ dpl. Tipe hutan yang digunakan oleh individu I dan II adalah hutan primer. Kedua kukang menggunakan daerah inti untuk travel, feeding, dan foraging hal ini didukung oleh vegetasi yang didominasi oleh kaliandra sebagai pakan, dan bungbuai sebagai tempat untuk mencari makan. Individu I memiliki tiga daerah inti, hal tersebut karena daerah inti individu I memiliki kontur yang berbukit-bukit. Individu II memiliki satu daerah inti.

Daerah tumpang tindih lebih sempit dibanding luas keseluruhan daerah jelajah individu I (10.49\%) dan individu II (10.21\%). Daerah tersebut memiliki vegetasi kaliandra dan pepohonan yang besar. Daerah tumpang tindih lebih banyak digunakan oleh individu I. Individu II hanya terlihat satu kali di daerah tersebut. Mereka tidak pernah terlihat bersama pada daerah tumpang tindih. Hal ini menunjukan keduanya memiliki sedikit interaksi.

Individu I menunjukan pertambahan luas daerah jelajah yang signifikan. Individu II tidak menunjukan pertambahan luas daerah jelajah yang signifikan selama pengamatan. Hal ini dimungkinkan karena individu I dalam kondisi bunting sehingga sangat sensitif dengan keberadaan pengamat, dan masih mencari tempat yang aman untuk melahirkan. Faktor tersebut juga menyebabkan kecepatan individu I berpindah saat menghindari gangguan lebih tinggi. Hal tersebut mengakibatkan individu I memiliki kecepatan yang lebih tinggi dengan jarak tempuh lebih pendek dibandingkan dengan individu II. Kukang yang diamati melakukan pergerakan dengan kecepatan rata-rata mencapai 1.42 hingga $1.53 \mathrm{~m} /$ menit. Hal tersebut lebih lambat dibandingkan dengan kecepatan Nycticebus coucang yang dilaporkan oleh Nekaris dan Bearder (2007), yaitu mencapai $6.66 \mathrm{~m} /$ menit.

Pergerakan daerah jelajah individu I meluas ke arah selatan, sedangkan pergerakan daerah jelajah individu II meluas ke arah barat (Gambar 13). Arah selatan daerah jelajah individu I terdapat banyak vegetasi untuk tempat mencari makan. Arah barat daerah jelajah individu II memiliki banyak potensi pakan dan mengarah ke jurang sungai kalimati. Kondisi jurang ini menyebabkan individu II tidak dapat teramati. Perubahan luas daerah jelajah diduga terjadi karena ketersediaan pakan dan kebutuhan terhadap rasa aman untuk melahirkan. Faktor yang dapat mempengaruhi pergerakan satwa liar adalah ketersediaan makanan, predator, dan waktu berkebembang biak (Alikodra 1990). Semakin sedikit ketersediaan sumber pakan maka semakin luas daerah jelajah satwa, dan semakin banyak ketersediaan sumber pakan maka luas daerah jelajah semakin menyempit.

Luas daerah individu I menyempit pada bulan maret menjadi 2.25 ha. Hal tersebut diduga terjadi karena individu I sedang dalam kondisi bunting dan akan melahirkan pada bulan April. Kedua daerah jelajah kukang jawa tersebut lebih luas dibandingkan dengan luas daerah jelajah kukang malaya pada hutan primer yang berada di Malaysia, yaitu sebesar 0.4-3.8 ha (Wiens 2002). Daerah jelajah kukang jawa hasil rehabilitasi lebih besar dibandingkan dengan kukang jawa liar. Kukang rehabilitasi YIARI memiliki luas daerah jelajah sebesar 29.21 ha (Moore et al. 2014). Kukang jawa hasil rehabilitasi tersebut setelah direintroduksi ke habitat alaminya, masih mencari daerah jelajahnya sendiri yang belum di kuasai oleh individu kukang lainnya. Daerah jelajah kukang jawa liar dalam penelitian ini masih mungkin akan bertambah mengingat waktu penelitian hanya dilakukan selama empat bulan. Penelitian mengenai slender loris (Genus: Loris) di Srilangka dan India, mengindikasikan bahwa di antara ordo primata, loris memiliki luas daerah jelajah 
Tabel 5. Uji chi-square parameter penggunaan ruang kukang jawa

\begin{tabular}{|c|c|c|c|c|c|c|}
\hline \multirow{2}{*}{$\begin{array}{c}\text { Parameter } \\
\text { penggunaan ruang }\end{array}$} & \multicolumn{3}{|c|}{ Individu I } & \multicolumn{3}{|c|}{ Individu II } \\
\hline & Nilai chi square $\left(\mathrm{x}^{2}\right)$ & df & Nilai p (Sig.) & Nilai chi square $\left(\mathrm{x}^{2}\right)$ & $\mathrm{df}$ & Nilai p (Sig.) \\
\hline Ukuran cabang & 30.94 & 24 & 0.000 & 62.34 & 12 & 0.002 \\
\hline Ketinggian posisi & 123.74 & 133 & 0.000 & 329.27 & 44 & 0.000 \\
\hline Jenis tumbuhan & 355.37 & 98 & 0.000 & 264.70 & 95 & 0.000 \\
\hline
\end{tabular}

mencapai 35 ha untuk ukuran tubuh 0.1 hingga $2.5 \mathrm{~kg}$ (Nekaris 2003; Wiens dan Zitzmann 2003; Wiens et al. 2006; Nekaris Bearder 2011). Secara umum besar tubuh dengan luas daerah jelajah saling berhubungan. Banyak primata yang memiliki ukuran tubuh lebih besar namun luas daerah jelajah yang digunakan lebih kecil dari loris ( $<35$ ha), misalnya Presbytis obscura (6.6 kg), Symphalangus syndactylus $(10.8 \mathrm{~kg})$ and Macaca fascicularis (5.9 kg) (Harvey dan CluttonBrock 1981; Campbell et al. 2011). Kukang termasuk dalam satwa yang dominan soliter (Charles-Dominique 1977; Bearder 1987), akan tetapi terdapat perilaku sosial pada kukang secara rutin, misalnya tidur dalam grup yang terdiri dari tujuh individu (Nekaris 2003; Wiens dan Zitzmann 2003; Nekaris 2006), dan terjadi tumpang tindih daerah jelajah, namun jarang terjadi pada kukang dewasa dengan jenis kelamin yang sama (Wiens dan Zitzmann 2003).

Individu I dan II dijumpai menggunakan pohon tidur dengan ketinggian antara 10 hingga 22 meter, dan memiliki karakter dipenuhi liana cangkole. Kukang yang diamati tidur di lokasi yang sama selama empat hingga lima hari. Jarak antar lokasi tidur individu I dan II yaitu sebesar 52.75 hingga 109.75 meter dari lokasi tidur selanjutnya. Dalam satu lokasi tidur individu I dan II terdapat beberapa pohon yang digunakan sebagai pohon tempat untuk tidur. Jarak antar pohon yang digunakan berkisar tiga hingga lima meter. Jenis pohon tidur yang digunakan yaitu kisampang, manglid, puspa, campaka gondok, pasang, dan kaliandra. Pemilihan tempat untuk tidur kukang malaya di Manjung Malaysia Barat adalah $73.7 \%$ pohon; $19.2 \%$ palem-paleman; $5.9 \%$ semak; $1.2 \%$ liana dengan tinggi di atas permukaan tanah 1.8-35 $\mathrm{m}$ (Wiens 2002). Vegetasi untuk tidur yang digunakan kukang ( $N$. javanicus dan $N$. coucang) di Indonesia adalah jenis pohon dan epifit seperti Asplenium nidus, Gigantochloa apus (Winarti 2003), Schima walichii, dan Gnetum cuspidatum (Widarteti 2003). Individu I dan II menggunakan kanopi bawah dengan ketinggian dua hingga delapan meter digunakan untuk mencari makan. Hal ini sama dengan kukang jawa di Bodogol Taman Nasional Gunung Gede Pangrango (TNGGP) serta di talun Tasikmalaya dan Ciamis (Pambudi 2008; Winarti 2011). Kukang jawa di talun menggunakan ketinggian posisi antara tiga hingga $12 \mathrm{~m}$ di atas permukaan tanah, untuk makan dan mencari makan
(Winarti 2011; Putri 2014). Kukang jawa di Hutan Bodogol TNGGP lebih sering terlihat di kanopi bawah dan kanopi tengah pohon. Kukang jawa di talun dapat menggunakan tumbuhan untuk tidur hingga ketinggian 25-30 $\mathrm{m}$ di atas permukaan tanah.

Stratum kanopi bawah yaitu terdiri dari pohonpohon dengan tinggi lima hingga $20 \mathrm{~m}$ dan tajuk kontinyu. Pohon-pohon dalam stratum ini rendah, kecil, banyak cabang yang tersusun rapat, dan berasosiasi dengan berbagai populasi epifit, tumbuhan memanjat dan parasit. Stratum kanopi tengah terdiri dari pohonpohon dengan tinggi 20-30 $\mathrm{m}$ dan tajuk kontinyu, batang pohon memiliki cabang yang banyak, batang bebas cabang tidak terlalu tunggi. Jenis pohon pada stratum ini toleran terhadap naungan. Individu I dan II menggunakan pohon untuk tidur dengan karakter tinggi dan besar, tajuk yang luas, jarak antar pohon yang dekat. Menurut Wiens 2002, kukang jawa sering terlihat tidur di antara cabang pohon dan liana yang rimbun, kukang jawa tidak membuat sarang atau tidur di lubang kayu.

Kaliandra (Calliandra calothrysus) merupakan tumbuhan berbuah polong dengan bunga tersusun majemuk berwarna merah. Bunga kaliandra memiliki nektar yang merupakan salah satu pakan dari kukang jawa. Bungbuai (Plectocomia elongate) merupakan tumbuhan berduri dari famili Arecaceae. Bungbuai memiliki sela-sela pelepah yang menjadi tempat bersarang serangga dan getah pada batangnya, keduanya merupakan pakan kukang jawa. Kisampang (Evodia latifolia) merupakan jenis pohon pengasil resin (Indrawan dan Primack 1998). Kisampang memilliki ukuran diameter batang yang besar dan tinggi, sehingga cocok untuk lokasi tempat tidur kukang jawa.

Kukang jawa tidur dengan posisi tubuh menggulung seperti bola. Vegetasi yang rapat dapat memberikan perlindungan kepada kukang dalam melakukan aktivitas hariannya. Kukang mempertahankan diri dengan mengandalkan warna tubuhnya yang samar dan bersembunyi di dalam vegetasi yang rapat. Hal tersebut diperlukan terutama pada saat kondisi paling rentan, yaitu saat kukang tidur (Pambudi 2008). Penggunaan posisi ketinggian kukang individu I lebih tinggi dibandingkan individu II, karena lokasi daerah jelajah individu I didominasi oleh pohon-pohon besar dan tinggi dengan tipe stratum tengah. 
Penggunaan ruang kedua individu kukang jawa yang diamati memiliki kesamaan yaitu pada penggunaan substrat kaliandra dan bungbuai, ukuran cabang ranting kecil, dan empat kontak. Perbedaan antara kedua individu terletak pada ketinggian posisi, dimana ketinggian posisi individu II dalam penggunaan ruang lebih rendah dibanding individu I. Hal ini diduga karena vegetasi pada daerah individu II lebih terbuka dibandingkan dengan daerah individu I.

Individu I lebih sering menggunakan bungbuai untuk tempat mencari pakan, berupa getah dan serangga. Bungbuai sering dikunjungi karena terdapat banyak pakan pada kedua pohon tersebut, seperti serangga di sela-sela batang dan getah pohon di tangkainya. Individu II lebih sering menggunakan kaliandra sebagai substrat untuk travel, feeding, dan foraging. Sebagian besar aktivitasnya dilakukan di pohon kaliandra untuk makan nektar. Hal tersebut sama dengan kukang jawa yang berada di Hutan Bodogol TNGGP, yang lebih banyak melakukan aktivitasnya di pohon kaliandra untuk memakan nektar (Pambudi 2008). Pohon kaliandra memiliki peranan penting bagi kukang jawa sebagai pohon pakan.

Hasil uji chi-square menunjukan bahwa perbedaan jenis substrat mempengaruhi penggunaan ruang. Hasil uji chi-square juga menunjukan bahwa ukuran cabang pohon memiliki pengaruh dalam penggunaan ruang. Ukuran ranting kecil digunakan untuk berpindah dari ranting satu ke ranting yang lain untuk mengambil pakan. Ukuran tubuh kukang yang relatif kecil, berat tubuhnya yang relatif ringan dan pola pergerakannya yang perlahan memungkinkan kukang memanfaatkan cabang dan ranting berukuran kecil atau ujung-ujung ranting untuk bergerak mencari pakan (Nekaris dan Rasmussen 2003). Menurut Pambudi (2008) meski secara perlahan dan terkesan hati-hati, kukang jawa dapat bergerak di antara ranting-ranting pohon yang berukuran kecil bahkan beberapa kali berada pada ujung ranting untuk mendapatkan buah, bunga, ataupun serangga. Cabang kecil digunakan untuk berpindah antara pohon kecil dan pohon besar. Cabang besar paling sedikit digunakan, karena ukuran tersebut sulit untuk digenggam untuk kukang. Berbeda dengan kukang jawa di Garut (Putri 2014), yang lebih suka menggunakan cabang ukuran sedang.

Awal bulan April individu I melahirkan, proses melahirkan tidak terlihat karena satu hari sebelum melahirkan individu I sulit ditemukan. Saat ditemukan, individu I bersikap agresif dan tidak tenang, kemudian terlihat individu I menggendong infant di perutnya. Dua hari kemudian individu I tidak diobservasi agar induk dan infantnya tidak terganggu dengan keberadaan pengamat. Pada observasi terakhir terlihat individu I melakukan infant parking dan meninggalkan infant di cabang kecil liana. Saat individu I kembali diobservasi, individu I tidak membawa infantnya. Setelah beberapa saat diamati, diketahui bahwa infantnya telah mati diantara cabang pohon.

\section{KESIMPULAN DAN SARAN}

Simpulan. Daerah jelajah kukang jawa berada di ketinggian 941.66 hingga $1361.1 \mathrm{~m}$ dpl. Luas daerah jelajah sebesar 5.58 hingga 5.44 ha. Vegetasi yang ada pada ketinggian tersebut didominasi oleh kaliandra, bungbuai, dan kisampang. Stratum ketinggian pohon yang digunakan oleh kukang jawa adalah kanopi bawah dengan ketinggian dua hingga 15 meter, dan stratum pohon kanopi tengah dengan ketinggian 15 hingga 22 meter. Perubahan luas daerah jelajah terjadi akibat ketersediaan sumber pakan dan kebutuhan terhadap rasa aman untuk melahirkan. Luas daerah tumpang tindih yang kecil (10\%) menunjukkan interaksi yang sedikit antara dua kukang. Penggunaan ruang dipengaruhi oleh jenis tumbuhan, ketinggian posisi dan ukuran cabang.

Saran. Penelitian mengenai daerah jelajah kukang jawa perlu dilakukan dalam jangka waktu yang lebih lama, sekitar satu tahun untuk mengetahui perbedaan luas daerah berdasarkan musim dan fenologi vegetasi. Perlu dilakukan habituasi yang lebih lama antara kukang liar dengan keberadaan pengamat.

\section{UCAPAN TERIMA KASIH}

Terima kasih kepada Yayasan IAR Indonesia dan Beasiswa Bidik Misi yang telah membantu sebagai pemilik project penelitian dan pemberi dana selama masa penelitian.

\section{DAFTAR PUSTAKA}

Alikodra HS. 1990. Pengelolaan Satwa Liar Jilid I. Departemen Pendidikan dan Kebudayaan. Bogor: Direktorat Jenderal Pendidikan Tinggi Pusat Antar Universitas Ilmu Hayati IPB.

Alikodra HS. 2002. Pengelolaan Satwa Liar. Bogor: Yayasan Penerbit Fakultas Kehutanan IPB.

Anderson J, Rowcliffe JM, Cowlishaw G. 2006. Does the matrix matter? A forest primates in a complex agricultural landscape. Biological Conservation 135:212-222.

Angeliza R. 2014. Aktivitas Harian Kukang Jawa (Nycticebus javanicus) di Taman Nasional Gunung Halimun Salak, Jawa Barat [Skripsi]. Bogor: Institut Pertanian Bogor.

Bearder SK. 1987. Lorises, bushbabies and tarsiers: Diverse societies in solitary foragers. In: Smuts B, Cheney D, Seyfarth R, Wrangham R, S. T (eds). Primate Societies Chicago: Chicago University Press. p 12-24.

Campbell CJ, Fuentes A, MacKinnon KC, Bearder SK, Stumpf RM. 2011. Primates in perspective. New York: Oxford University Press.

Charles-Dominique P. 1977. Ecology and behaviour of nocturnal primates: prosimians of equatorial West Africa. New York: Columbia University Press. 
Collins RL. 2007. Behavioral data of captive greater slow loris (Nycticebus coucang) and Javan slow loris $(N$. javanicus)and a survey of Javan slow loris in Mt. Salak, West Java [Disertasi]. Oxford: Departemen Antropologi Oxford Brookes University.

Fitch-Snyder H, Schulze H, Larson L. 2001. Management of lorises in captivity. A husbandry manual for Asian Lorisines (Nycticebus and Loris spp.). Zoological Society of San Diego. San Diego: Center for Reproduction in Endangered Species.

Fleagle JG. 1999. Primate adaptation and evolution: Academic Press.

Fryxell JM, Sinclair RE. 1988. Causes and consequenses of migration by large herbivores. Trends in Ecology and evolution 9:237-241.

Glassman DM, Wells JP. 1984. Positional and activity behavior in a captive slow loris: A quantitative assessment. American Journal of Primatology 7:121-132.

Gursky S. 1998. Effects of radio transmitter weight on a small nocturnal primate. American Journal of Primatology 46:145-155.

Gursky S. 2003. Lunarphilia in a nocturnal primate. International Journal of Primatology 24:351-367.

Hartono TH, Kobayashi H, Widjaya M, Suparmo 2007. Taman Nasional Gunung Halimun-Salak, Edisi revisi. Bogor: JICA-BTNGHS-Puslit Biologi LIPI-PHKA.

Harvey PH, Clutton-Brock TH. 1981. Primate home-range size and metabolic needs. Behavioral Ecology and Sociobiology 8:151-155.

Hasan M, Feeroz M, Islam M, Kabir M, Begum S. 2007. Substrate use by the western hoolock gibbon (Hoolock hoolock) in a semievergreen forest of Bangladesh. Zoo's Print Journal 22:2701-2705.

Indrawan M, Primack BR. 1998. Biologi Konservasi. Indonesia: Yayasan Obor Indonesia.

Irwanto. 2014. Gambar Stratum pohon hutan hujan tropis Tersedia di: www.irwantoshut.net [Data akses: $20 \mathrm{Mei}$ 2014]

IUCN. 2011. IUCN Red List of Threatened Species.

IUCN. 2013. IUCN Red List of Threatened Species Version 2013. Tersedia di: www.iucnredlist.org [Data akses: 26 November 2013]

Izard MK, Weisenseel KA, Ange RL. 1988. Reproduction in the slow loris (Nycticebus coucang). American Journal of Primatology 16:331-339.

Johns AD, Skorupa JP. 1987. Responses of rain-forest primates to habitat disturbance: A review. International Journal of Primatology 8:157-191.

Juarez CP, Rotundo MA, Berg W, Fernandez E-Duque. 2011. Cost and benefit of radio-collaring on the behavior, demography, and conservation of Owl Monkeys (Aotus azarai). International Journal of Primatology 32:6982.

Kusmana C. 1997. Metode Survey Vegetasi. Bogor: Institut Pertanian Bogor.

Laurance WF. 1990. Comparative responses of five arboreal marsupial to tropical forest fragmentation. American Society of Mammalogists 71:641-653.

Longman KA, Jenik J. 1987. Tropical forest and its enviroment. $2^{\text {nd }}$ eds. Singapure: ELBS publishing.

MacKinnon J, MacKinnon K. 1987. Conservation status of primates in Malesia, with special reference to Indonesia Primate Conservation 8:175-183.

Martin P, Bateson P. 1993. Measuring Behaviour. 2 eds. London: Cambridge University Br.

Mech D. 1983. Handbook of Animal Radio-Tracking. Menneapolis: University of Minnesota Press.

Moore SR. 2012. Ethics, ecology and evolution of Indonesian slow lorises (Nycticebus spp.) rescued from the pet trade [Thesis]. Oxford: Oxford Brookes University.
Moore SR, Huda R, Sanchez KL. 2014. Home range size and use in translocated Nycticebus javanicus in halimun salak national park, west java. In: International Primatology Society Conference XXV. Hanoi: International Primatology Society. $\mathrm{p} 375$.

Nandini R, Kakati K, Ved N. 2009. Occurence records of the Bengal slow loris (Nycticebus bengalensis) in Northeastern India. American Journal of Primatology $1: 12-18$

Napier JR, Napier PH. 1967. A Handbook of Living Primates. New York: Academic Press.

Napier JR, Napier PH. 1985. The Natural History of The Primates. Cambridge: The MIT Press.

Nekaris KAI. 2003. Spacing system of the Mysore slender loris (Loris lydekkerianus lydekkerianus). American Journal of Physical Anthropology 121:86-96.

Nekaris KAI, Rasmussen DT. 2003. Diet and feeding behavior of Mysore slender lorises. International Journal of Primatology 24:33-46.

Nekaris KAI. 2006. Social lives of adult mysore slender lorises (Loris lydekkerianus lydekkerianus). American Journal of Primatology 68:1171-1182.

Nekaris KAI, Bearder SK. 2007. The Lorisiform Primates of Asia and Mainland Africa: Diversity shrouded in darkness. Dalam: Campbell C, Fuentes A, MacKinnon K, Panger M, Bearder SK (eds). Primates in Perspective. Oxford: Oxford University Press.

Nekaris KAI, Jaffe S. 2007. Unexpected diversity of slow lorises (Nycticebus spp.) within the Javan pet trade: impications for slow loris taxonomy. Contributions to Zoology 76:187-196.

Nekaris KAI, Nijman V. 2007. CITES proposal highlights threat to nocturnal primates Nycticebus: Lorisidae. Folia Primatology 78:211-214.

Nekaris KAI, Blackham GV, Nijman V. 2008. Conservation implications of low encounter rates of five nocturnal primate species (Nycticebus spp.) in Asia. Biodiversity and Conservation 17:733-747.

Nekaris KAI et al. 2008. Javan Slow Loris Nycticebus javanicus É. Geoffroy, 1812. In: Mittermeier et al. 2009. Primates in Peril: The World's 25 Most Endangered Primates 2008-2010. Bogota: Panamericana Formas e Impresos SA.

Nekaris KAI, Munds R. 2010. Using facial markings to unmark diversity: The slow lorises (Primates: Lorisidae: Nycticebus spp.) of Indonesia. In: Gursky-Doyen S, Supriatna J (eds).Indonesian primates. New York: Springer. p 383-396.

Nekaris KAI, Starr CR, Collins RL, WilsonA. 2010. Comparative ecology of exudate feeding by lorises (Nycticebus, Loris) and pottos (Perodicticus, Arctocebus). In: A. M. Burrows and L. T. Nash (eds). The Evolution of Exudativory in Primates. New York: Springer. p 155168.

Nekaris KAI, Bearder SK. 2011. The lorisiform primates of Asia and mainland Africa: Diversity shrouded in darkness. In: C. J. Campbell, A. Fuentes, K. C. MacKinnon, S. K. Bearder and R. M. Stumpf. Primates in Perspective. Oxford: Oxford University Press.

Nijman V, Van Balen SB. 1998. A faunal survey of the Dieng Mountains, Central Java, Indonesia: Distribution and conservation of endemic primate taxa. Oryx 32:146158.

Nowak RM. 1999. Walker's Primate of The World. New York: The Jhons Hopkin's.

Odum EP. 1998. Dasar-dasar Ekologi. Ed ke-3. T. Samingan, penerjemah. Yogyakarta: Gadjah Mada University Press. 
Osfeld RS, Lidicker WZ, Heske EJ. 1988. The relationship between habitat heterogenity, space use and demography in population of california voles. Oikos 45:433.

Pambudi JAA. 2008. Studi populasi, perilaku, dan ekologi kukang jawa (Nycticebus javanicus E. Geoffroy, 1812) di hutan bodogol taman nasional gunung gede pangrango jawa barat [Tesis]. Jakarta: Universitas Indonesia.

Putri RP. 2014. Aktivitas harian dan penggunaan habitat kukang jawa (Nycticebus javanicus) di talun desa cipaganti, garut, jawa barat [Skripsi]. Jakarta: Universitas Indonesia.

Rodger AR. 2001. Recent telemetry technology. In: Millspaugh, J.J. dan J.M. Marzluff (eds). Radio tracking and animal populations. San Diego: Academic press.

Rowe N. 1996. The Pictorial Guide to The Living Primates. New York: Pogonian Press.

Schulze H. 2002. Age Determination in Lorises and Pottos Tersedia di: http://www.lorisconservation.org/database/ population_database/Standards_for_Measurement/ age determination.html [Data akses: 8 Desember 2007]

Schulze H. 2003. Distribution of Slow Loris Forms. Tersedia di: http://www.lorisconservation.org/database/ distribution_maps/05_slow_lorises.html [Data akses: 8 April 2003]

Schulze H, Groves G. 2004. Asian lorises: taxonomic problems caused by illegal trade. In: Nadler T, Streicher U, Ha TL. International Symposium Conservation of Primates in Vietnam. Hanoi: Haki Press. p 33-36.

Setchell JM, Curtis DJ. 2003. Field and Laboratory Methods in Primatology A Practical Guide. United Kingdom: Cambridge University Press.

Streicher U. 2004. Aspects of the ecology and conservation of the pygmy loris Nycticebus pygmaeus in Vietnam [Disertasi]. Muenchen: Ludwig-MaximiliansUniversität.

Swapna N. 2008. Assessing the feeding ecology of the Bengal slow loris (Nycticebus bengalensis) in Trishna Wildlife Sanctuary, Tripura [Tesis]. Bangalore: National Centre for Biological Sciences.

Thohari M. 1989. Teknologi pemantauan satwa liar dengan radio telemetri. Media Konservasi 2:51-61.

Thorn JS, Nijman V, Smith D, Nekaris, KAI. 2009. Ecological niche modelling as a technique for assessing threats and setting conservation priorities for Asian slow lorises (Primates: Nycticebus). Diversity and Distributions 15:289-298.

[TNGHS] Gunung Halimun Salak National Park Management Project-JICA. 2008. Merajut Pesona Flora Hutan Pegunungan Tropis di Gunung Salak. LIPI-JICA.
Trent BK, Tucker ME, Lockard JS, 1977. Activity changes with illumination in slow loris Nycticebus coucang. Appl Anim Ethol 3:281-286.

Trezs H. 2003. Enviromental enrichment for nonhuman primates. Phoenix zoo: Phoenix.

Wiens F. 2002. Behavior and ecology of wild slow lorises (Nycticebus coucang): sosial organisation, infant care system and diet [Disertasi]. Bayreuth: Bayreuth University.

Wiens F, Zitzmann A. 2003. Social structure of the solitary slow loris Nycticebus coucang (Lorisidae). Journal of Zoology 261:35-46.

Wiens F, Zitzmann A, Hussein NA. 2006. Fast food for slow lorises: Is low metabolism related to secondary compounds in high-energy plant diet?. Journal of Mammalogy 87:790-798.

Winarti I. 2003. Distribusi dan struktur vegetasi habitat kukang (Nycticebus coucang Boddaert 1785) di desa marga mekar, kecamatan sumedang selatan, sumedang, jawa barat [Skripsi]. Bandung: Universitas Padjajaran.

Winarti I. 2011. Habitat, populasi dan sebaran kukang jawa (Nycticebus javanicus Geoffroy 1812) di talun tasikmalaya dan ciamis, jawa barat [Tesis]. Bogor: Institut Pertanian Bogor.

Wirdateti. 2003. Pengamatan Nycticebus coucang (kukang) di Taman Nasional Gunung Halimun. Fauna Indonesia 5:49-54.

Wirdateti. 2005. Pakan alami dan habitat kukang Nycticebus coucang dan tarsius Tarsius bancanus di hutan Pasir Panjang Kalimantan Tengah. Journal Biology Indonesia 3:360-370.

Wirdateti, Suparno, 2006. Survey Habitat dan Perdagangan Nycticebus coucang dan Tarsius di Palembang dan Prabumulih Sumatera Selatan [Laporan Perjalanan, tidak d ipublikasikan]. Bogor: LIPI.

Worton BJ. 1989. Kernel methods for estimating the utilization distribution in home-range studies Ecology. 70:164168.

[YIARI] Yayasan International Animal Rescue Indonesia. 2013. Laporan teknis pelepasliaran dan pemantauan paska pelepasliaran Kukang Jawa ( $N$. javanicus) di Kawasan Hutan Gunung Salak-Taman Nasional Gunung Halimun Salak. Bogor: YIARI.

[YIARI] Yayasan International Animal Rescue Indonesia. 2014. Metode Pengamatan Perilaku Kukang: Parameter yang Diamati. Bogor: YIARI.

Zimmermann E. 1989. Reproduction, physical growth and behavioral development in slow loris (Nycticebus coucang, Lorisidae). Human Evolution 4:171-179. 